\title{
2006-95: DEVELOPMENT OF AN ARTIFICIAL ORGAN DESIGN COURSE
}

\section{Conrad Zapanta, Pennsylvania State University}

Conrad M. Zapanta is an Assistant Professor of Surgery and Bioengineering at The Pennsylvania State University in Hershey, PA. Dr. Zapanta received his Ph.D. in Bioengineering from the Pennsylvania State University in University Park, PA, and his B.S. in Mechanical Engineering (with an option in Biomedical Engineering) from Carnegie Mellon University in Pittsburgh, PA. Dr. Zapanta has served as a Visiting Assistant Professor of Engineering at Hope College in Holland, MI, and an Adjunct Professor of Engineering at Austin Community College in Austin, TX. He also worked for CarboMedics Inc. in Austin, TX, in the research and development of prosthetic heart valves. Dr. Zapanta's research interests include circulatory support devices, prosthetic heart valves, cardiovascular fluid dynamics, and medical device design and education.

\section{Keefe Manning, Pennsylvania State University}

Keefe B. Manning is an Assistant Professor of Bioengineering at The Pennsylvania State University in University Park, PA. Dr. Manning received his Ph.D. in Biomedical Engineering at the Virginia Commonwealth University in Richmond, VA and his M.S. and B.S. in Biomedical Engineering at Texas A\&M University in College Station, TX. He was a post doctoral scholar in Bioengineering at The Pennsylvania State University. Currently, he is a board member for the American Society for Artificial Internal Organs. His research interests include cardiovascular fluid dynamics, cardiovascular prosthetics (artificial hearts, ventricular assist devices, mechanical heart valves), and hemorheology. 


\title{
Development of an Artificial Organ Design Course
}

\begin{abstract}
Over the last 50 years, artificial organs have had a significant impact on the types and quality of medical care available today. In order to address this important field, the Department of Bioengineering at the Pennsylvania State University offers a course entitled "Artificial Organ Design." This senior and graduate level course emphasizes the following objectives:

1. Understanding engineering design and problem solving techniques with special emphasis placed on the Food and Drug Administration's design control process for medical devices.

2. Familiarity with various engineering issues surrounding the design of artificial organs including biomaterials and biocompatibility, design principles for tissue and blood contact, power systems for implanted systems, and control of artificial organs.

3. Understanding the regulatory approval process for artificial organs including codes and regulations, reliability, and device testing.

4. Application of this knowledge to the design of artificial organs including circulatory support devices, drug delivery systems, artificial lungs and oxygenators, artificial kidney, pacemakers, neural prostheses, prosthetic heart valves, orthopedic implants, bioartificial organs (tissue engineering), and cardiopulmonary bypass. These lectures demonstrate how the techniques and knowledge presented in the first part of the class are applied to the design of artificial organs. The students then complete a final design project for an artificial organ of their own choosing.
\end{abstract}

\section{Introduction}

Artificial organs have a significant impact on the types and quality of medical care available today. Artificial organs treat over 4.8 million patients a year in the United States and have improved the quality of life of over 24.4 million people. ${ }^{1}$ In order to expose students to this important field, the Department of Bioengineering at the Pennsylvania State University offers a course entitled "Artificial Organs Design."

The Department of Bioengineering at the Pennsylvania State University has its roots in the artificial heart program. This program began as a collaborative effort in 1970 between faculty members of the Colleges of Engineering and Medicine. This initial effort resulted in a pneumatic ventricular assist device that was first implanted in 1976 and was later purchased by Thoratec ${ }^{\circledR}$ Corporation (Pleasanton, CA). ${ }^{2}$ Over 2,850 implants of this device have occurred worldwide, with the longest duration of 566 days. ${ }^{3}$ Later collaborative efforts have produced a totally implantable electric left ventricular assist device ${ }^{4}$ and an electric total artificial heart. ${ }^{5} \mathrm{~A}$ 
separate collaboration between the College of Engineering and Medicine led to the development of an intravascular artificial lung., 7

These successes in artificial organs research and development gave the impetus for a class that taught students the tools necessary for successful artificial organ design. The course was entitled "Artificial Organ Design" and was first offered in 1991. The Artificial Organ Design course is offered as an elective intended for juniors, seniors and graduate students. The class is primarily composed of bioengineering majors (undergraduate and graduate students) with the remaining come from other engineering disciplines such as electrical, chemical, and mechanical engineering.

The course has been taught approximately every two years with an average class enrollment of 12 undergraduate and graduate students. However, the enrollment more than doubled in the Spring of 2005. This sudden increase in enrollment is due to the establishment of an undergraduate major in Bioengineering in 2003. The current student enrollment in the Department of Bioengineering at the Pennsylvania State University consists of 86 undergraduates and 46 graduate students. In addition, fifteen undergraduates are seeking minors in Bioengineering.

\section{Course Objectives}

The Artificial Organ Design course has the following objectives:

1. Understanding engineering design and problem solving techniques

2. Building familiarity with the specific engineering issues surrounding the design of artificial organs

3. Understanding the process of obtaining regulatory approval for artificial organs

4. Application of these techniques and knowledge to the design of artificial organs

\section{Course Description}

In order to meet these objectives, the class was organized into a series of lectures, assignments, and exams based on the class outline presented in Table 1. Approximately 50\% of the lectures were given by a primary lecturer who was based at the College of Medicine (in Hershey, PA). The remaining lectures were given by guest lecturers drawn from other departments within the Colleges of Engineering (in University Park, PA) and Medicine. These departments included bioengineering, surgery, orthopedics, anesthesia, and pediatrics. This team-teaching arrangement combined the continuity of a primary lecturer with the expertise of several contributors from different areas. 


\section{Introduction to Artificial Organs}

2. Engineering Background

a. Engineering Design Principles and Problem Solving

b. Review of Fundamental Engineering Principles

3. Specific Engineering Issues regarding Artificial Organs

a. Biomaterials and Biocompatibility

i. Mechanical Properties and Testing

ii. Types of Materials

iii. Structure/Function Relationships in Biomaterials

iv. Failure Mechanisms in Biomaterials

v. Surface Properties and Host Response (Biocompatibility)

b. Design Principles for Tissue and Blood Contact

c. Power Systems for Implanted Systems

d. Control of Artificial Organs

4. Obtaining Regulatory Approval

a. Codes and Regulations

b. Reliability and Device Testing

c. Medical Device Industry

5. Examples of Artificial Organs

a. Circulatory Support Devices

b. Drug Delivery

c. Artificial Lungs and Oxygenators

d. Artificial Kidney

e. Pacemakers

f. Neural Prostheses

g. Prosthetic Heart Valves

h. Orthopedics

i. Bioartificial Organs

j. Cardiopulmonary Bypass

Table 1: Artificial Organ Design Class Outline

The course began with a series of lectures on engineering design and problem solving techniques. Special emphasis was placed on using the Food and Drug Administration's (FDA) design control process for medical devices. ${ }^{8}$ A brief review of fundamental engineering equations was also provided using examples of artificial organs. For instance, blood flow through an oxygenator was used to illustrate the conservation of mass.

The course then continued with a series of lectures dealing with engineering issues specific to the design of artificial organs. These issues include biomaterials and biocompatibility, design principles for tissue and blood contact, power systems for implanted systems, and control of 
artificial organs. As these lectures were presented, examples were drawn from the development of the artificial heart and ventricular assist device at the Pennsylvania State University. ${ }^{9-11}$

A series of lectures that detailed the process of obtaining regulatory approval for artificial organs was then presented. These topics included lectures on codes and regulations for different types of artificial organs, and reliability and device testing. Special emphasis was placed on reviewing FDA protocols and applications for prosthetic heart valves and artificial hearts. A series of lectures were also presented on the artificial organ (medical device) industry. These lectures included topics on careers in artificial organs in academia and industry, grant writing, and funding streams.

The remaining lecture portion of the course described different examples of artificial organs, drawing heavily on the concepts introduced previously. These artificial organs included circulatory support devices, drug delivery systems, artificial lungs and oxygenators, artificial kidney, pacemakers, neural prostheses, prosthetic heart valves, orthopedic implants, bioartificial organs (tissue engineering), and cardiopulmonary bypass. These presentations were structured to clearly demonstrate how the techniques and knowledge presented in the first part of the class were applied to the design of artificial organs.

Students applied the knowledge from the course in a final written project that described the design of an artificial organ (or some aspect thereof) of their own choosing. The project included the following items:

- Clear definition of the medical problem that necessitated an artificial organ

- Analysis of currently available designs

- List of detailed design specifications

- Description of the design that clearly demonstrated how the proposed design met the design specifications and how it was different from currently available designs

- Quantitative engineering analysis

- Failure mode analysis (with special emphasis placed on how the proposed design addressed these potential failure modes)

- $\quad$ Testing plan (in vitro and in vivo)

- Complete bibliography

\section{Results}

The class was offered with the format presented in the previous section in the Fall of 2002 and the Spring of 2005. The results of these two offerings are described below. Examples of the final project and class evaluations are also presented.

\section{1 $\quad$ Fall 2002 Offering}

The class offered in the Fall of 2002 was composed of 4 undergraduates and 7 graduate students. Of these 11 students, four students were located with the primary instructor and the majority of 
the guest lecturers at the College of Medicine. The remaining students were at the College of Engineering, which is located over 100 miles away from the College of Medicine. Because of this physical separation, PictureTel (PicTel, Polycom Inc., Pleasanton, CA) was used to link the two classes together. In addition, an on-line course management system (ANGEL, Angel Learning, Indianapolis, IN) was used to allow students and instructors at both campuses to quickly and easily access the class handouts, homework, and announcements prior to and after class. The primary instructor also made periodic visits to the College of Engineering to give lectures and to meet with students face-to-face. These visits resulted in increased interaction between the instructors and students despite this exclusive use of PicTel.

Following the completion of the Fall 2002 offering, student and faculty evaluations were used to assess the class and identify additions and changes. These evaluations recommended the addition of lectures on bioartificial organs (tissue engineering) and the artificial lung, further clarification of when class assignments are due, additional visits to the College of Engineering by the primary instructor, and limiting most topics to one class to allow additional topics to be covered. These changes were implemented when the class was next offered in the Spring of 2005.

\section{2 $\quad$ Spring 2005 Offering}

For the Spring of 2005, the enrollment increased to 28 students (20 undergraduates and 8 graduate students). The primary instructor and three students were at the College of Medicine, while the remaining students were at the College of Engineering. PicTel and ANGEL were again utilized to address the distance between the primary instructor and the vast majority of the students. In order to assist with class management and grading, a co-instructor was added at the College of Engineering. Lectures on careers in artificial organs in academia and industry were added. The primary instructor also doubled the number of visits to the College of Engineering.

In addition to the final design project, a second design project was assigned to the graduate students in order to differentiate between the undergraduate and graduate students. This design project involved the design of a common artificial organ (artificial liver). This commonality permitted each graduate student to compare and contrast his/her design with those of other graduate students.

Student and faculty evaluations after the Spring of 2005 identified areas of improvement. These included a reorganization of the final project to require different due dates for specific progress points (literature review, design specifications, etc.) throughout the semester and the addition of a group project. Lectures on design for manufacturability and GMP (good manufacturing practices) standards for artificial organs were suggested. Finally, opportunities to tour hospitals and other medical facilities were suggested to allow the students to observe artificial organs in clinical use. 


\subsection{Design Project}

Selected artificial organ design projects from the Fall of 2002 and the Spring of 2005 are listed in Table 2. Each design project was the result of constant interaction between each student and the primary instructor and/or co-instructor. Each student was required to turn in ideas for his/her design project early in the semester. After a project was selected and approved, detailed design specifications and a summary of the medical significance for the project were submitted to the primary instructor for review and returned to the students with comments prior to the completion of the final project.

\begin{tabular}{|c|c|}
\hline 1. & A design study of an interventional catheter tip \\
\hline 2. & Design for a cartilage tissue engineering implant \\
\hline 3. & Design of an anti-reflux valve for use with esophageal stents \\
\hline 4. & A fully implantable microphone model for use in cochlear prostheses \\
\hline 5. & Design of an inferior vena cava filter \\
\hline 6. & Photolithographic techniques to sustain liver cells \\
\hline 7. & Porous media matching for an artificial liver construct \\
\hline 8. & Membranes for molecular adsorbents recycling systems \\
\hline 9. & $\begin{array}{l}\text { Prothrombin monitoring device for anti-coagulation therapy or delivery of cholesterol } \\
\text { fighting statin drugs }\end{array}$ \\
\hline 10 . & $\begin{array}{l}\text { Dual-approach (hybrid) artificial liver utilizing artificial filtration and cultured } \\
\text { hepatocytes }\end{array}$ \\
\hline 11. & Method to improve hepatocyte isolation to maintain viability and function \\
\hline 12. & $\begin{array}{l}\text { Design of an artificial patellar tendon extension for the treatment of Osgood Schlatter's } \\
\text { disease }\end{array}$ \\
\hline 13. & Artificial gallbladder and bile control system \\
\hline 14. & Low cost functional finger prosthesis \\
\hline 15. & Design of a transtibial ankle-foot prosthetic \\
\hline 16. & Design of a bioadsorbable tracheal stent for the management of tracheal stenosis \\
\hline 17. & Design of a catheter for peritoneal dialysis \\
\hline 18. & Design of a fully implantable bioartificial pancreas \\
\hline 19. & Internal recharger for a myo-electric hand prosthetic \\
\hline 20. & $\begin{array}{l}\text { A temporary aortic repair patch for ruptured aneurysms in the thoracic and abdominal } \\
\text { aortas }\end{array}$ \\
\hline 21. & Thyroid hormone sensor \\
\hline 22. & Fully implantable artificial larynx \\
\hline 23. & $\begin{array}{l}\text { Extracorporeal dialysis unit using perfusable cell-lined catridges for the treatment of } \\
\text { acute renal failure }\end{array}$ \\
\hline 24. & Clotting tendency monitor for a heart-lung machine \\
\hline 25. & $\begin{array}{l}\text { Implantable and rechargeable vagus nerve stimulator for the treatment of treatment } \\
\text { resistant depression }\end{array}$ \\
\hline 26. & Design of a pancreatic assist device for type 1 diabetes patients \\
\hline
\end{tabular}

Table 2: Selected Artificial Organ Design Projects from Fall 2002 and Spring 2005 
Both oral and written presentations by were required for all of the students in the Fall of 2002. However, logistical concerns in the Spring of 2005 limited the oral presentations to the common artificial liver projects that were completed by the graduate students. Written presentations were required for both the common graduate student projects and the final design project.

For the Spring of 2005, the final design projects were used to introduce the topic of grant funding and peer review. Each design project was assigned three reviewers who had similar final project topics to the one being reviewed. The students then reviewed each other's projects and assigned scores using the review criteria and methodology used by the National Institutes of Health Center for Scientific Review. ${ }^{12}$ The scores were rank-percentiled by the primary instructor who then awarded "funding" to the top $15 \%$ of the projects in the form of Hershey's Kisses ${ }^{\circledR}$.

\subsection{Class Evaluations}

Class evaluations were conducted at then end of each offering using the Student Rating of Teaching Effectiveness (STRE) which is utilized at the Pennsylvania State University. The SRTE assesses teaching effectiveness with questions that evaluate teaching processes and outcomes. ${ }^{13}$ The results of the STRE for the Fall 2002 and Spring 2005 offerings of the Artificial Organ Design course are summarized in Table 3. For the Spring 2005 offering, the undergraduate and graduate students are separated into different categories.

For Fall of 2002, seven out of then nine areas received average scores higher than 6.0. The highest scores were for effectiveness in demonstrating the significance of the subject matter, and the overall quality of instructor(s). The lowest scores were for adequacy of the physical facilities and the instructional resources.

For Spring of 2005, the undergraduates rated all nine areas higher than 6.0. The undergraduates gave the highest scores to the effectiveness in demonstrating significance of the subject matter and the instructor's interest in whether or not the students understood the course content. The undergraduates gave the lowest scores for clarity of instructor's interpretation of abstract ideas and adequacy of physical facilities. The graduate students rated eight out of nine areas higher than 6.0. The graduate students rated effectiveness in demonstrating and significance and instructor's skill in encouraging students to think as the highest. The lowest rated areas were adequacy of instructional resources and overall quality of the course.

Table 4 lists representative student comments of the Fall 2002 and Spring 2005 offerings of the course. In general, the students liked the application-oriented nature of the course. The major dislikes were the widespread use of PicTel and the lack of hands-on experiences with examples of artificial organs. 


\begin{tabular}{|l|c|c|c|}
\hline \multicolumn{1}{|c|}{ Category } & $\begin{array}{c}\text { Fall 2002 } \\
\text { All Students }\end{array}$ & $\begin{array}{c}\text { Spring 2005 } \\
\text { Undergraduate } \\
\text { Students }\end{array}$ & $\begin{array}{c}\text { Spring 2005 } \\
\text { Graduate } \\
\text { Students }\end{array}$ \\
\hline Overall quality of course & 6.44 & 6.35 & 6.00 \\
\hline Overall quality of instructor(s) & 6.56 & 6.45 & 6.57 \\
\hline Clarity of instructor's presentations & 6.33 & 6.25 & 6.29 \\
\hline $\begin{array}{l}\text { Clarity of instructor's interpretations } \\
\text { of abstract ideas and theories }\end{array}$ & 6.00 & 6.16 & 6.29 \\
\hline $\begin{array}{l}\text { Instructor's interest in whether or } \\
\text { not students understood course } \\
\text { content }\end{array}$ & & & 6.29 \\
\hline $\begin{array}{l}\text { Effectiveness of instructor(s) in } \\
\text { demonstrating significance of } \\
\text { subject matter }\end{array}$ & 6.11 & 6.45 & 6.71 \\
\hline $\begin{array}{l}\text { Instructor's skill in encouraging } \\
\text { students to think }\end{array}$ & 6.67 & 6.55 & 6.71 \\
\hline $\begin{array}{l}\text { Adequacy of physical facilities for } \\
\text { instruction }\end{array}$ & 6.00 & 6.15 & 6.43 \\
\hline $\begin{array}{l}\text { Adequacy of instructional resources } \\
\text { (text, AV equipments, guest } \\
\text { speakers, supplies, manuals, etc.) }\end{array}$ & & & \\
\hline
\end{tabular}

Table 3: SRTE (Student Rating of Teaching Effectiveness) Results for

Fall of 2002 and Spring of 2005

Scale: 1 (Lowest) --- 7 (Highest) 
What did you like best about this course?

- The practical application emphasis. (2002)

- The real-world problem based approach of the entire course made it very interesting. The literature search and the final project - design made it possible to understand a problem better and apply what we learned (design process - what to look for, etc.) through the course. (2002)

- I liked the fact that the lecture topics were extremely diverse and the variation in teachers made this better for the most part. (2002)

- Good industry focus, wide range of topics, start from basics. Despite PicTel/distance, course was very interactive and rewarding. (2005)

- This is one of the best (top 2 or 3 ) courses I have taken in my 4 yrs. I learned a lot about a topic I have always only heard mentioned as a future scientific possibility. (2005)

- I enjoyed learned about he (sic) design that goes into the engineering of artificial organs. Call me a masochist, but I actually really enjoyed doing the design project! (2005)

- I liked the independent nature of the projects (no prodding along the way $\&$ freedom to work on your own ideas.) (2005)

What did you like least about this course?

- Confusion about homework - when due. Very different homework from different professors. (2002)

- PicTel isn't as good at keeping my attention as an actual professor. (2002)

- The fact that it was after lunch and many of the lecturers were broadcast from Hershey. It led to a lot of dozing off. (2005)

- I think this class lacked actual visualizations of the artificial organs. (2005)

- That I couldn't get a hands-on feel for the applications of the artificial organs. (2005)

- Would like more engineering backbone (what equations need solved and what assumptions are made.) (2005)

- The classical engineering was a little light...I think most people have already seen the straight conservation egns before. I would have like to have seen more application specific problems. (2005)

What suggestions do you have for improving this course?

- More lectures related to tissue engineering, artificial organs. (2002)

- Try to make most topics only one day of coverage except for things like biomaterials. Then more topics can be covered. (2002)

- The project should definitely be divided up more and progress check throughout the semester. This would help us do better and organize our ideas better. (2005)

- Bring in more clinicians/industry workers for perspective. Maybe include something related to cancer if possible (or diabetes). (2005)

- Based on inputs taken in the beginning of the course, ask graduate and undergraduate students to work in groups with each student handling a specific component determined by his/her interest. Thus have two big projects during the course, a group project and an individual project. (2005) 


\section{Course Assessment and ABET Criteria}

Table 5 lists the ABET program outcomes and assessments adopted by the Bioengineering faculty. These are based upon the ABET criteria required for certification of the undergraduate program in Bioengineering. This certification process is anticipated to occur in 2008.

\begin{tabular}{|c|c|c|c|}
\hline ABET Outcome & $\begin{array}{c}\text { Homework } \\
\text { problems }\end{array}$ & $\underset{\text { problems }}{\text { Exam }}$ & $\begin{array}{c}\text { Final } \\
\text { proiect }\end{array}$ \\
\hline $\begin{array}{l}\text { 1. An ability to apply knowledge of advanced } \\
\text { mathematics, science, and engineering to solve } \\
\text { problems at the interface of engineering and } \\
\text { biology }\end{array}$ & 5 & 4 & 1 \\
\hline $\begin{array}{l}\text { 2. An ability to design and conduct experiments, as } \\
\text { well as to analyze and interpret data from living } \\
\text { and non-living systems }\end{array}$ & - & 1 & 1 \\
\hline $\begin{array}{l}\text { 3. An ability to design a system, component, or } \\
\text { process to meet desired needs within realistic } \\
\text { constraints. }\end{array}$ & 2 & 3 & 1 \\
\hline 4. An ability to function on multi-disciplinary teams & - & - & - \\
\hline $\begin{array}{l}\text { 5. An ability to identify, formulate, and solve } \\
\text { engineering problems }\end{array}$ & 3 & 4 & 1 \\
\hline $\begin{array}{l}\text { 6. An understanding of professional and ethical } \\
\text { responsibility }\end{array}$ & 2 & - & - \\
\hline An ability to communicate effectively & 1 & - & 1 \\
\hline $\begin{array}{l}\text { 8. The broad education necessary to understand the } \\
\text { impact of engineering solutions in a global, } \\
\text { economic, environmental, and societal context }\end{array}$ & 1 & - & 1 \\
\hline $\begin{array}{l}\text { 9. A recognition of the need for, and an ability to } \\
\text { engage in, life-long learning }\end{array}$ & - & - & - \\
\hline 10. A knowledge of contemporary issues & 1 & 4 & 1 \\
\hline $\begin{array}{l}\text { 11. An ability to use the techniques, skills, and } \\
\text { modern engineering tools necessary for } \\
\text { engineering practice }\end{array}$ & 6 & 8 & 1 \\
\hline $\begin{array}{l}\text { 12. An understanding of physics, chemistry, and of } \\
\text { physiology at molecular, cellular and organ levels. }\end{array}$ & 2 & 10 & 1 \\
\hline $\begin{array}{l}\text { 13. An ability to address problems associated with the } \\
\text { interaction between living and non-living materials } \\
\text { and systems }\end{array}$ & 3 & 8 & 1 \\
\hline $\begin{array}{l}\text { 14. An understanding of statistics as applied to } \\
\text { experimental design }\end{array}$ & - & - & - \\
\hline $\begin{array}{l}\text { 15. An in-depth knowledge of a specific area of } \\
\text { bioengineering: bioelectricity, biomechanics, } \\
\text { biomaterials or biotransport }\end{array}$ & - & - & - \\
\hline
\end{tabular}

Table 5: Evaluation of Class in Addressing ABET Outcomes for the Department of Bioengineering 
An assessment of the artificial organ design class was conducted following the Spring of 2005 in order to determine how the course met these outcomes. The results of this review are also summarized in Table 5. This table lists the number of times each outcome was addressed through homework assignments, exam problems, and the final project. For example, outcome \#1 was addressed throughout the Spring of 2005 by five homework problems, four exam problems, and the final project.

This evaluation revealed that 11 out of the 15 outcomes $(73.3 \%)$ were directly addressed by this course. The percentage is among the highest of all of the courses offered by the Department of Bioengineering. Outcomes \#11 (ability to use techniques, skills, and modern engineering tools), \#12 (understanding of physics, chemistry, and physiology), and \#13 (interaction between living and non-living materials and systems) were addressed the most times, while outcomes \#2 (design and conduct experiments), \#6 (professional and ethical responsibility), and \#8 (impact of engineering solutions) were addressed the least number of times. Outcomes that were not addressed by the class were outcomes \#4 (teams), \#9 (life-long learning), \#14 (statistics), and \#15 (in-depth knowledge of a specific area).

The student scores for each homework problem, exam problem, and applicable area of the final project for each ABET outcome listed in Table 5 were also tabulated. Areas in which the more than $50 \%$ of the students received a score below $80 \%$ were identified as potential areas of improvement. These areas included cardiopulmonary bypass, control and power systems, stents, failure modes, pacemakers, drug delivery, and neuroprosthesis. The instructors of these specific areas were consulted to determine how these scores can be improved for future class offerings.

\section{Conclusion}

This paper has described the development of an artificial organ design course at the Pennsylvania State University. The objectives of this course are to understand engineering design and problem solving techniques, become familiar with various engineering issues surrounding the design of artificial organs, understand the process of obtaining regulatory approval for artificial organs, and apply these techniques and knowledge to the design of artificial organs. The current offering of this course in the Spring of 2006 reflects this continuous development.

\section{Acknowledgements}

The authors would like to recognize the significant contributions of Gerson Rosenberg, Ph.D., who founded the initial version of this class in 1991. The authors also recognize the faculty members from the Colleges of Engineering and Medicine who have participated in this class over the last 15 years.

\section{Bibliography}


1. M.J. Lysaght and J.A. O'Loughlin, Demographic scope and economic magnitude of contemporary organ replacement therapies, ASAIO J, 46(5): 515-21, 2000.

2. W.E. Richenbacher and W.S. Pierce, Assisted Circulation and the Mechanical Heart. E. Braunwald, Editor. Heart Disease: A Textbook of Cardiovascular Medicine, Sixth Edition. W.B. Saunders Company: Philadelphia. p. 534-547 2001.

3. $\quad$ Thoratec VAD Clinical Results, November 2004.

4. A. El-Banayosy, L. Arusoglu, L. Kizner, M. Morshuis, G. Tenderich, W.E. Pae, Jr., and R. Korfer, Preliminary experience with the LionHeart left ventricular assist device in patients with end-stage heart failure, Annals of Thoracic Surgery, 75(5): 1469-75, 2003.

5. W.J. Weiss, G. Rosenberg, A.J. Snyder, W.S. Pierce, W.E. Pae, H. Kuroda, M.A. Rawhouser, G. Felder, J.D. Reibson, T.J. Cleary, S.K. Ford, J.A. Marlotte, R.A. Nazarian, and D.L. Hicks, Steady state hemodynamic and energetic characterization of the Penn State/3M Health Care Total Artificial Heart, ASAIO Journal, 45(3): 189-93, 1999.

6. H. Baskaran, V. Nodelman, J.S. Ultman, R.B. Richard, G. Panol, K.M. High, and M.T. Snider, Small intrapulmonary artery lung prototypes. Mathematical modeling of gas transfer, ASAIO J, 42(5): M597-603, 1996.

7. M.T. Snider, K.M. High, R.B. Richard, G. Panol, E.A. Campbell, C.V. Service, J.K. Stene, and J.S. Ultman, Small intrapulmonary artery lung prototypes: design, construction, and in vitro water testing, ASAIO J, 40(3): M533-9, 1994.

8. $\quad$ Food and Drug Administration, Design Control Guidance for Medical Device Manufacturers, Department of Health and Human Services. 1997.

9. G. Rosenberg, Artificial Heart and Circulatory Assist Devices. J. Bronzino, Editor. The Biomedical Engineering Handbook. CRC Press: Boca Raton, FL. p. 1839-1846 1995.

10. H. Yamanaka, G. Rosenberg, W.J. Weiss, A.J. Snyder, C.M. Zapanta, and C.A. Siedlecki, Multiscale analysis of surface thrombosis in vivo in a left ventricular assist system, ASAIO J, 51(5): 567-77, 2005.

11. C.M. Zapanta, A.J. Snyder, W.J. Weiss, T.J. Cleary, J.D. Reibson, M.A. Rawhouser, J.P. Lewis, W.S. Pierce, and G. Rosenberg, Durability testing of a completely implantable electric total artificial heart, ASAIO J, 51(3): 214-23, 2005.

12. National Institutes of Health Center for Scientific Review, http://cms.csr.nih.gov/ResourcesforApplicants/PolicyProcedureReview+Guidelines/, Accessed December 27, 2005.

13. The Pennsylvania State University Schreyer Institute for Teaching Excellence, http://srte.site.psu.edu/Default.asp, Accessed December 27, 2005. 